only to postgraduate students (full-time and parttime). The percentage of undergraduate students from overseas is only 10 per cent. The total number of full-time overseas students has been rising steadily since the programme of expansion started in 1953, but the proportion has scarcely changed. In 1952-53 there were 312 from overseas out of a total of 1,653 full-time students, or 19 per cent. Last session the corresponding figures were 528 out of 2,437 , or 22 per cent. The number this term is 552 out of 2,580 , or 21 per cent.

\section{The Night Sky in December}

New moon occurs on Dec. 10d. 17h. 23m. U.T., and full moon on Dec. 26d. 03h. 54m. The following conjunctions with the Moon take place: Dec. 22d. 05h., Mars $4^{\circ} \mathrm{N}$. Mercury rises about two hours before the Sun at the end of the month, but conditions are not favourable for observation. Venus is too close to the Sun for observation. Mars sets at 6h. $05 \mathrm{~m}$., 4h. $55 \mathrm{~m}$. and $4 \mathrm{~h} .00 \mathrm{~m}$. at the beginning, middle and end of the month, respectively. Mars retrogrades until December 20, after which date it resumes its eastward motion among the stars; it is in Aries throughout December. Its stellar magnitude decreases during the month from $-\mathbf{l} \cdot 6$ to $-0 \cdot 6$, its distance from the Earth increasing from 49 to 67 million miles. Jupiter rises at $5 \mathrm{~h}$. $50 \mathrm{~m}$., $5 \mathrm{~h} .10 \mathrm{~m}$. and $4 \mathrm{~h} .25 \mathrm{~m}$. on December 1,15 and 31 , respectively; it is east of $\alpha$ Libræ. The stellar magnitude of Jupiter is -1.3 ; conditions for observation are not very favourable. Saturn is too close to the Sun for observation. Occultations of stars brighter than magnitude 6 are as follows, observations being made at Greenwich: Dec. 23d. 22h. 33.6m., $\delta$ Tau. $(D)$; Dec. 23d. 23h. 03.2m., 64 Tau. $(D)$; Dec. 28d. $20 \mathrm{~h}$. $29.2 \mathrm{~m} ., A^{1}$ Cnc. $(R)$; Dec. 29d. 04h. 04.0m., $\alpha$ Cnc. $(D)$; Dec. $29 \mathrm{~d}$. 04h. 59.8m., $\alpha$ Cnc. $(R) . \quad D$ and $R$ refer to disappearance and reappearance, respectively. The Geminid meteors are active during December 9-14, conditions being very favourable; the radiant is near R.A. 7 h. $28 \mathrm{~m}$., Dec. $+32^{\circ}$. The Ursid meteors are active on December 21, but conditions for observation are unfavourable. The winter solstice occurs on Dec. 22d. 09h.

\section{Announcements}

ON November 22, H.M. the Queen conferred the Order of Merit on Viscount Samuel. This award is a tribute to a life-time of devoted public service, including fifty years as a Privy Councillor.

Dr. Vittorino Veronese, a lawyer and formerly president of Catholic Action in Italy, has been elected director-general of the United Nations Educational, Scientific and Cultural Organization for a period of six years.

THE managing trustees of the Drummond Irust will consider, in March 1959, applications for a Drummond Fellowship for research in nutrition. It may be a Senior or Junior Fellowship, depending on the qualifications of the person selected. The value of a Senior Fellowship would be $£ 1,100$ per annum with expenses grant and superannuation, and of a Junior Fellowship $£ 500$ per annum with expenses grant. The Fellowship will normally be tenable for two years. Full particulars can be obtained from the Honorary Secretary, Drummond Trust, University College London, Gower Street, W.C.1. Completed applica- tion forms must be received not later than January 31,1959 .

The Royal Agricultural Society of England offers annually a medal together with an award of one hundred guineas for research work of outstanding merit carried out in the United Kingdom which has proved, or is likely to prove, of benefit to agriculture. Recommendations for this award can be made by the heads of university departments, research stations and institutes. No direct application by candidates will be considered. Recommendations for the next award must be submitted to the Secretary, Royal Agricultural Society of England, 35 Belgrave Square, London, S.W.1, not later than January 31, 1959, accompanied by nine copies of a brief statement of the candidate's attainments and a list of his publications.

The fourth Biennial Conference on Carbon, on "The Physics and Chemistry of Carbon Surfaces", will be held at the University of Buffalo during June 15-19, 1959. Information can be obtained from Carbon Conference, University of Buffalo, Buffalo 14, New York.

A MeEtrang of the Parasitology Group, Institute of Biology, will be held in Edinburgh during March 19-23, 1959. The closing date for registration is February 28. Further particulars of the meeting can be obtained from Miss J. Mahon, Department of Zoology, Bedford College, Regent's Park, London, N.W.1.

THE Institution of Electrical Engineers is holding a Convention on Thermo-Nuclear Processes, during April 29-30, 1959. The probable range of topies is as follows: basic physics of thermonuclear processes; prototype British thermonuclear experiments; constructional features of ZETA 1 ; design problems of future ZETA-type systems ; possibilities of direct conversion from nuclear to electrical energy. Further information can be obtained from the Secretary, Institution of Electrical Engineers, Savoy Place, London, W.C.2.

THE next meeting of the Plant Phenolics Group will be held on January 6, 1959, at the Queen Elizabeth College, London, W.8, under the chairmanship of Prof. R. D. Haworth. The subject will be "Chemistry of Condensed Tannins". Speakers will include Drs. B. Brown, D. E. Hathway, W. E. Hillis, E. A. H. Roberts, D. Roux and T. Swain. Further information can be obtained from the honorary secretary, Dr. T. Swain, Low Temperature Research Station, Downing Street, Cambridge.

UNDER the provisions of the Fulbright Programme, travel grants are available to citizens of the United Kingdom and dependent territories to go to the United States for an academic or educational purpose, provided that they have financial support in dollars for the visit, and have been accepted by an American institution of higher learning. Grants cover the cost of direct travel between a candidate's home and the American university or institution, and are available during June 1, 1959-April 1, 1960. Applications must be submitted by March 14, 1959 (for those travelling between June 1, 1959, and August 15, 1959) or by June 1, 1959 (for those travelling between August 16, 1959, and April 1, 1960). Application forms and further information can be obtained from the United States Educational Commission in the United Kingdom, 71 South Audley Street, London, W.1. 